\title{
SLC5A2 Gene
}

National Cancer Institute

\section{Source}

National Cancer Institute. SLC5A2 Gene. NCI Thesaurus. Code C119004.

This gene is involved in the transport of both glucose and sodium. 